\title{
Theoretical and Experimental Study of Steel Props Used in Concrete Buildings
}

\author{
Cleirton André S. Freitas, Francisco J. P. Almeida, Ailton T. Silva, and Wagner O. Batista
}

\begin{abstract}
In concrete structures molded in situ it is necessary to use temporary structures, called prop. These support the actions of the permanent loads and variable as well, while the fresh concrete becomes self-supporting. Support posts are normally made from wood or steel. Little reuse, deforestation and low productivity are the disadvantages of the wood column application, against of advantage of the low cost. On the other hand, steel column presents high productivity, time reduces and not only high reuse but also it is renewable. This work was carried out on the criteria design, experimental tests and computational simulation of the steel support post. The design criteria used in this research it's from the Brazilian standard. The lab tests were applied in six typical size prototypes. And finally, for the computational simulation was developed one specific program called FLEP. The results show an especial care of parameter buckling in the Brazilian design criteria and the program FLEP as well, for to obtain the same result in experimental tests.
\end{abstract}

Index Terms_FLEP program, lab test of prop, steel prop.

\section{INTRODUCTION}

The prop system consists of temporary structures made of wood or steel, which is intended to hold the shape of the concrete [1]. The steel prop can be reused in many different kinds of works; has load capacity greater than wood; precision leveling; fast and secure mounting; and also great durability [2]. Its use in residential and commercial buildings with ceiling height until 3.50 meters [3].

The steel props are used during construction, alteration, demolition and maintenance works [4]. However, structural failures of these systems have occurred on construction sites in the past, due to inadequate design, poor installation and over-loading, which would cause not only project delays but more seriously injuries of the construction workers [5].

A large compression load can cause the column to become unstable, resulting in a sudden lateral deflection of the column. This bowing of the column is called buckling. The purpose of the Euler buckling calculations is to compute the magnitude of the axial load that will create this instability in the column [6].

Factors that dictate the load required to buckle a column include the dimensions and configuration of the column cross-section, the length of the column, the elastic modulus and the restraint provided by the connections at the supports.

Euler buckling considers an ideal column, which assumes

Manuscript received March 20, 2014; revised May 24, 2014. This work was supported in part by the FUNCAP and UFCA.

The authors are with the Federal University of Ceará - UFC Cariri Campus, Cidade Universitária, Juazeiro do Norte, 630000 Ceará, Brazil (e-mail: andrefreitas@cariri.ufc.br). that: the column is perfectly straight before loading; the column material is homogenous; the load is applied through the centroid of the column's cross-section; and the material stresses remain in the linear-elastic region of the stress-strain curve. While these assumptions are never truly met in practical columns, Euler buckling serves to introduce the concept of stability as a failure consideration [7].

Despite of the importance of this prop system, there is not a procedure for accurate sizing, and an experimental study for validation is needed. This is because the steel prop is formed by a set of pieces with different strength. They are composed of four parts: the inner tube with one top plate; the outer tube with bottom plate and external thread; Handle of adjust; and a pin of fixation (Fig. 1). Table I shows the geometry data used for manufacturing the tubes.

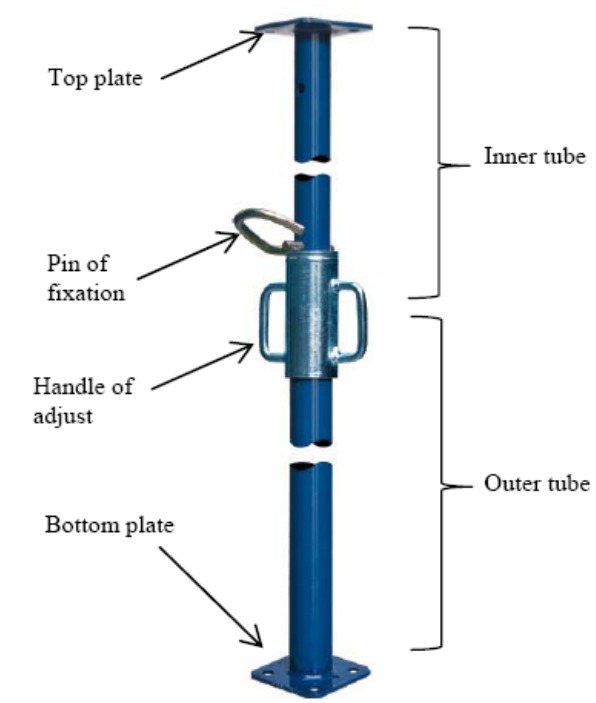

Fig. 1. Elements the adjustable steel props.

TABLE I : Tube Dimensions of THE SteEl ProP

\begin{tabular}{ccccc}
\hline \multicolumn{5}{c}{ OUTER TUBE (STEEL ABNT MR 250) } \\
\hline TYPE OF SECTION & $\begin{array}{c}\text { LENGTH } \\
(\mathrm{mm})\end{array}$ & $\begin{array}{c}\text { OUTER } \\
\text { DIAMETER } \\
(\mathrm{mm})\end{array}$ & $\begin{array}{c}\text { INNER } \\
\text { DIAMETER } \\
(\mathrm{mm})\end{array}$ & $\begin{array}{c}\text { THICKNESS } \\
(\mathrm{mm})\end{array}$ \\
\hline TUBE CIRCULAR & 1500 & 52 & 48 & 2 \\
\hline & INNER TUBE (STEEL ABNT MR 250) \\
\hline \multicolumn{5}{c}{ OUTER } \\
TYNGTH OF SECTION & $\begin{array}{c}\text { INAMETER } \\
(\mathrm{mm})\end{array}$ & $\begin{array}{c}\text { DIAMETER } \\
(\mathrm{mm})\end{array}$ & $\begin{array}{c}\text { THICKNESS } \\
(\mathrm{mm})\end{array}$ \\
\hline TUBE CIRCULAR & 1600 & 42 & 38 & 2 \\
\hline \hline
\end{tabular}

\section{TheoreticAl Foundations For Design OF PRoPs}

According to [8], long and thin elements submitted to an axial compression are called columns, and the lateral deflection is called buckling. The ruin of a compression member is frequently driven by critical load of buckling, 
unless there is local instability of its components. For the design of tubular steel prop, was adopted in this work the Brazilian standard NBR 8800/08 [9]. The Equation (1) shows a axial force resistance in compression $\left(N_{c, R d}\right)$, associated with instability-limits by bending, torsional and local buckling.

$$
N_{c, R d}=\frac{\chi Q A_{g} f_{y}}{\gamma_{a 1}}
$$

where,

$\chi$ is a reduction factor associated with compression;

$Q$ is a reduction factor associated with local buckling;

$A_{g}$ is a cross section area;

$f_{y}$ is a yield stress of steel;

$\gamma_{a 1}$ is equal to 1,10 in normal case.

In the circular tubular sections, the reduction factor for local buckling $(Q)$, according to [9], is given by (2) or (3). For the props studied in this work was used $Q$ equal to 1 .

$$
\begin{aligned}
\text { If, } \frac{D}{t} & \leq 0,11 \frac{E}{f_{y}} \text { then: } Q=1 \\
\text { If, } 0,11 \frac{E}{f_{y}}<\frac{D}{t} & \leq 0,45 \frac{E}{f_{y}} \text { then: } Q=\frac{0,038}{(D / t)} \frac{E}{f_{y}} \frac{2}{3}
\end{aligned}
$$

where,

$D$ is an outer diameter of tube;

$t$ is a thickness of tube;

$E$ is an Young's modulus of material.

The reduction factor $(\chi)$ is obtained by (4) or (5), accordance with slenderness ratio $\left(\lambda_{\mathrm{o}}\right)$ by $(6)$. The axial force of elastic bucking $\left(N_{e}\right)$ is obtained by (7).

$$
\begin{gathered}
\text { If, } \lambda_{\mathrm{o}} \leq 1,5 \text { then: } \chi=0,658^{\lambda_{0}^{2}} \\
\text { If, } \lambda_{\mathrm{o}}>1,5 \quad \text { then: } \chi=0,658 / \lambda_{0}^{2} \\
\lambda_{0}=\sqrt{\frac{Q A_{g} f_{y}}{N_{e}}} \\
N_{e}=\frac{E I \pi^{2}}{(K L)^{2}}
\end{gathered}
$$

where,

$K$ is a buckling coefficient;

$L$ is a free length;

$I$ is a moments of inertia of the section.

\section{Methodology}

In this work were developed an experimental study, an analysis of the computational model through the FLEP software [10] and a prop sizing following the NBR 15696/09 [11] and NBR 8800/08. Thus, were adopted steel props with 3.10 meters, and the results of the study these three methods were compared.

The first step, experimental tests, was developed in the laboratory of structures at the Federal University of Cariri. The samples of steel props were obtained in the local market in the town of the Juazeiro no Norte. Among the data analyzed, the principal was the load capacity.

The next step was the computational study with the program FLEP (Linear and Elastic Buckling of Plane Frame). This program was developed by [10], through the finite element method (F. E. M). Two models were adopted for verification of buckling, as well as the value critical load.

In the third stage was the sizing following the recommendations of the NBR 15696/09 and NBR 8800/08. Three hypotheses of theoretical models for the props were studied. Were considered the props made only with inner tube the props made only with outer tube and the props made with both inner and outer tube.

\section{EXPERIMENTAL STUDY}

Experimental tests were performed in five samples of steel prop. These were built and instrumented according with Fig. 2. Two steel supports were required and fixed on floor by bolts. The load was gradually applied to the prop by hydraulic jack (Hidraumon with load capacity of 15ton or $15000 \mathrm{kgf}$ ). It was controlled by hydraulic pump (Hidraumon of $3 \mathrm{CV}$ and 700bar) and their components, such as electric engine, oil compartment box and control valve Fig. 3 . The measuring system of the displacement were composed by Dial Test Indicator (DTI), DTI Support, Load cell (RS-5000 Excel - maximum of $5000 \mathrm{Kgf}$ ) and Reading panel (HBM WE2108).

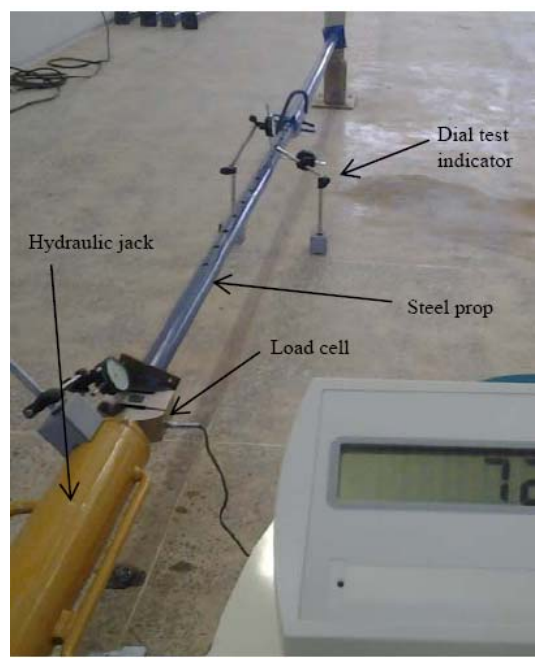

Fig. 2. Experimental study of the adjustable steel prop.

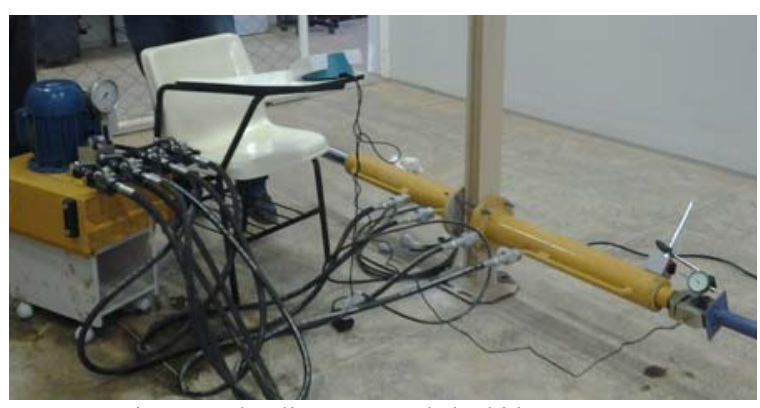

Fig. 3. Hydraulic pump made by hidraumon.

The load step was applied with increment of $100 \mathrm{kgf}$. Then, a longitudinal displacement was read by one DTI on top. The lateral deflection was also read by two DTI installed at a 
distance of $1.30 \mathrm{~m}$ from the base (Fig. 4 and Fig. 5).

The load was increased until the point where the prop showed instability. It is the time when there was deformation without load increase. Table II shows the values of the applied loads.

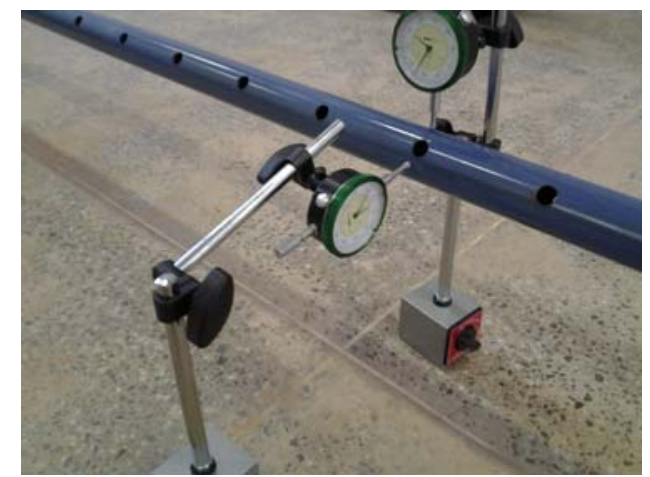

Fig. 4. Measuring of lateral deflection with dial test indicator.

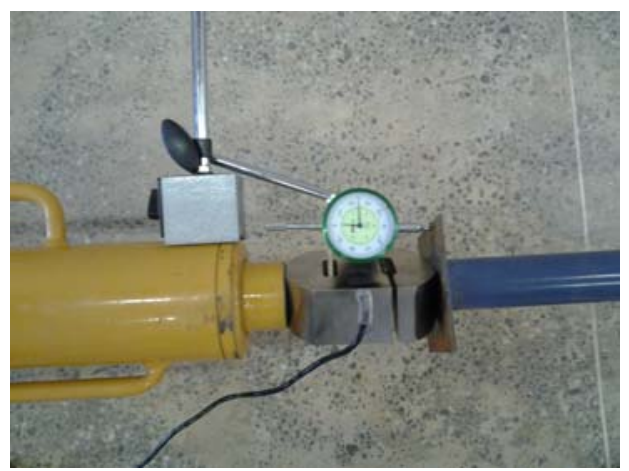

Fig. 5. Dial test indicator on top of prop.

TABLE II: APPLIED LOAD AT THE STEEL PROPS

\begin{tabular}{c|c|c|c|c|c}
\hline \hline Steel prop & 1 & 2 & 3 & 4 & 5 \\
\hline Steps & $\begin{array}{c}\text { Load } \\
(\mathrm{kgf})\end{array}$ & $\begin{array}{c}\text { Load } \\
(\mathrm{kgf})\end{array}$ & $\begin{array}{c}\text { Load } \\
(\mathrm{kgf})\end{array}$ & $\begin{array}{c}\text { Load } \\
(\mathrm{kgf})\end{array}$ & $\begin{array}{c}\text { Load } \\
(\mathrm{kgf})\end{array}$ \\
\hline 1 & 107 & 113 & 108 & 612 & 130 \\
\hline 2 & 600 & 330 & 320 & 785 & 360 \\
\hline 3 & 697 & 420 & 520 & 815 & 508 \\
\hline 4 & 799 & 505 & 705 & 850 & 705 \\
\hline 5 & 900 & 700 & 900 & 900 & 900 \\
\hline 6 & 1200 & 900 & 1100 & 980 & 1106 \\
\hline 7 & 1311 & 995 & 1300 & 1025 & 1305 \\
\hline 8 & 1408 & 1190 & 1400 & 1200 & 1500 \\
\hline 9 & 1500 & 1300 & 1500 & 1300 & 1600 \\
\hline 10 & 1600 & 1400 & - & 1440 & 1800 \\
\hline 11 & - & 1500 & - & 1540 & - \\
\hline 12 & - & 1600 & - & 1740 & - \\
\hline \hline Average of loads (kgf) & & 1650 \\
\hline \hline 6
\end{tabular}

The critical load used was the average of the maximum loads supported $\left(P_{c r}=1650 \mathrm{kgf}\right)$. The prototypes had little lateral displacement during test until the buckling load as shown in Fig. 6. The results of all props were similar behavior to prop 1, Fig. 7. The lateral displacement was less than $4 \mathrm{~mm}$ at the maximum load.

The collapse occurred always in the inner tube. The increase of displacement with decrease of load occurred after the critical load as shown in Fig. 8.

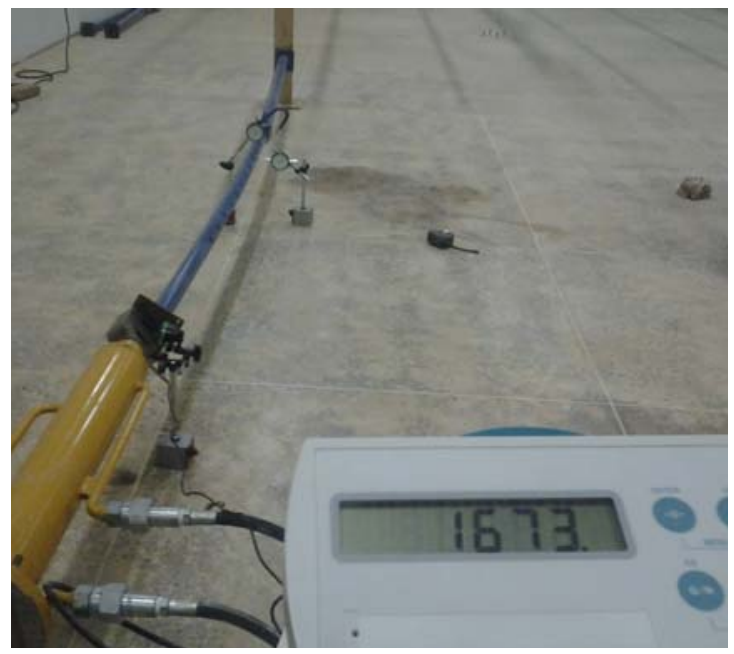

Fig. 6. Visual displacement of the steel prop at the load $1673 \mathrm{kgf}$.

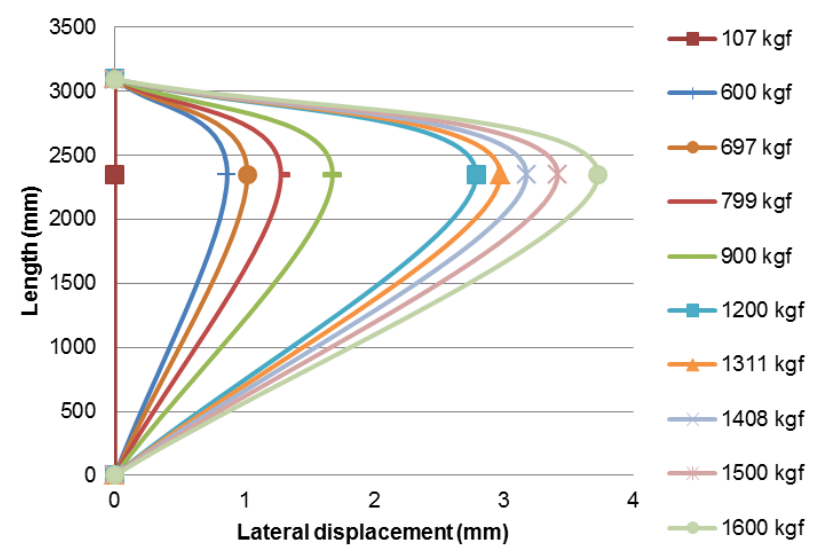

Fig. 7. Lateral deflection of the steel prop 1.

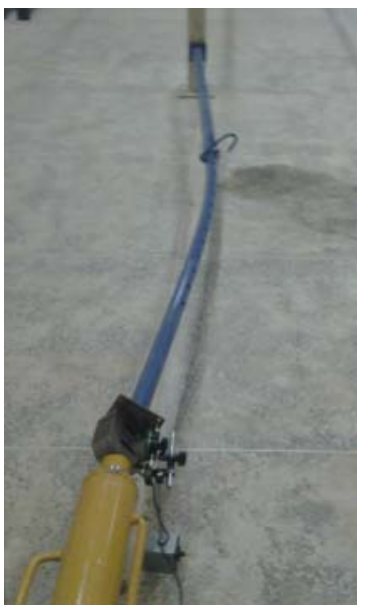

Fig. 8. Increase of displacement with decrease of load.

\section{Computational Study (M.E.F.)}

The computational study was developed by FLEP program [10]; that was used the finite element method. This was implemented with frame element, in which is possible to apply external loads and thermal loads. It is possible to calculate the elastic buckling load, the nodal displacements, reactions, bending moment, and shear force.

The formulation used in the FLEP program was based on the direct stiffness method. Initially, the internal forces in the structural members were obtained, for the applied loading. 
From these efforts, geometric stiffness matrices were obtained, for each element. The equilibrium equations of the structure were represented by (8).

$$
\begin{gathered}
{\left[K_{t}\right]\{d\}=\{F\}} \\
{\left[K_{t}\right]=\left[K_{e}\right]+\bar{\lambda}^{[}\left[\bar{K}_{g}\right]}
\end{gathered}
$$

where,

$\left[K_{t}\right]$ is the tangent stiffness matrix;

$\{d\}$ are the nodal displacements;

$\{F\}$ are the combined nodal forces;

$\left[K_{e}\right]$ is the elastic stiffness matrix;

$\bar{\lambda}$ is dimensionless quantity;

$\left[\bar{K}_{g}\right]$ is the geometric stiffness matrix;

The lowest value of $\bar{\lambda}$, which makes singular the matrix $\left[K_{t}\right]$ in (9), is the value of the critical load of linear elastic buckling of the structure.

In the FLEP program was used a method based on the bisection algorithm. Where, the tangent stiffness matrix of the structure $\left[K_{t}\right]$ was factored for many values of dimensionless quantity $\bar{\lambda}$. For this, the Cholesk method was used. Finally was obtained the value of the linear elastic critical load.

The Frame element was used for two-dimensional modeling. It is link by two nodes; having three degrees of freedom per node. Two computational models were adopted in this step. The first was discretized with rigid roller and pinned support. The second model was discretized considering elastic support because of end plate.

\section{A. Model with Rigid Support (FLEP 1)}

In this model was disregarded the bottom and top plate of prop. The prop discretization is shown in Fig. 9. Observe that outer tube and inner tube are made by four frame elements. For the supports were used roller and pinned. The model was run with a unit axial load compression in the negative direction of $\mathrm{Y}$ axis, in order to find a value of critical load. Value of the critical load was about $13,76 \mathrm{kN}$ or $1376 \mathrm{kgf}$.

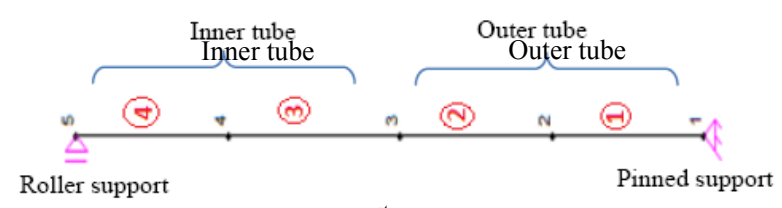

Fig. 9. Discretization of the $1^{\text {st }}$ model by M.E.F (FLEP program).

\section{B. Model with Elastic Support (FLEP 2)}

In the second model was considered the presence of bottom plate and top plate of the prop, as shown in Fig. 10. To represent stiffness of the plates were added in the model an elastic spring.

The model was run with a unit axial load compression in the negative direction of $\mathrm{Y}$ axis, in order to find a value of critical load. Value of the critical load was about $15.84 \mathrm{kN}$ or 1584 kgf.

The elastic stiffness of support $\left(K_{\text {rotz }}\right)$ was calculated to simulate the stiffness of the prop plate. According to [12], the stiffness of an elastic support is numerically equal to the force that causes unit displacement of this support.

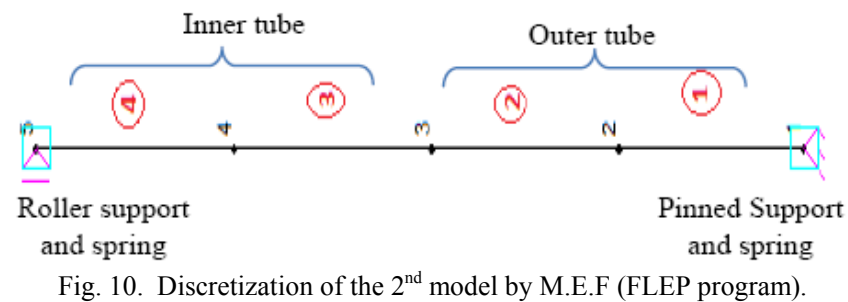

The elastic stiffness of support $\left(K_{\text {rotz }}\right)$ was calculated to simulate the stiffness of the prop plate. According to [12], the stiffness of an elastic support is numerically equal to the force that causes unit displacement of this support. Then, plate was considered as shown in Fig. 11 and the free body diagram of plate in Fig. 12.

Unit rotation in the counterclockwise direction was applied in the middle of the bar. Besides, was considered a constant of cross section. Then, was obtained the stiffness coefficient, about $168 \mathrm{kN} . \mathrm{cm} / \mathrm{rad}$, through of coefficients sum, as shown in (8).

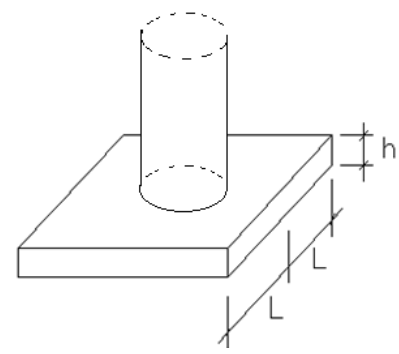

Fig. 11. Plate illustration of steel prop

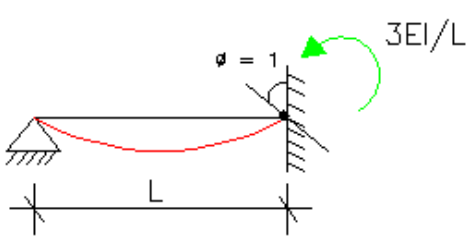

Fig. 12. Free body diagram of plate.

$$
K_{\text {RotZ }}=\frac{3 E I}{L}+\frac{3 E I}{L}=\frac{6 E I}{L}
$$

\section{ANALYTICAL STUDY}

The theoretical study was based on NBR15696/09 that references the NBR $8800 / 08$ for design of tubular members. The NBR 8800/08 does not refer the compression sizing of the tubes with variable circular section. In this study were adopted three hypotheses for design of tubular steel prop.

In the first case was considered the steel prop made only with inner tube. In the second hypothesis was adopted only the outer tube. And in the third were adopted the two sections, inner and outer tube, with their respective lengths.

\section{A. Application of the First Hypothesis: Inner Tube (NBR1)}

Was adopted a single cross section for all length of prop, inner tube equal to $42 \mathrm{~mm}$ and thickness about $2 \mathrm{~mm}$. In Fig. 13 are shown the characteristics of the prop for this 
hypothesis. After the application of the theoretical foundations for design of steel props by (1) to (7) was obtained axial force resistance $\left(N_{c, R d}\right)$ equal to $845.0 \mathrm{kgf}$.

Tube $\varnothing 42 \mathrm{~mm}-\mathrm{K}=1$

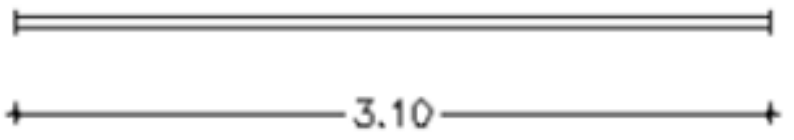

Fig. 13. Geometry of the $1^{\text {st }}$ Hypothesis using inner tube.

\section{B. Application of the Second Hypothesis: Outer Tube (NBR2)}

Was adopted a single cross section for all length of prop, outer tube equal to $52 \mathrm{~mm}$ and thickness about $2 \mathrm{~mm}$. In Fig. 14 are shown the characteristics of the prop for this hypothesis. The axial force resistance $\left(N_{c, R d}\right)$ equal to 1648.0 kgf was obtained by (1) to (7).

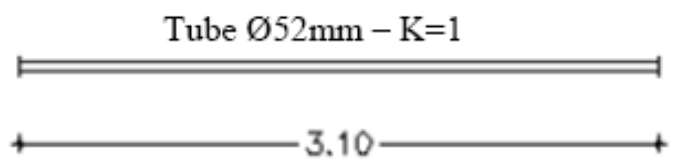

Fig. 14. Geometry of the $2^{\text {nd }}$ Hypothesis using outer tube.

\section{Application of the Third Hypothesis: Inner and Outer Tube (NBR3)}

The prop characteristics for the $3^{\text {rd }}$ case are shown in Fig. 15. This hypothesis differs from the previous because here were considered the two sections, each with its actual length and its corresponding buckling coefficient $(k=1.4)$.

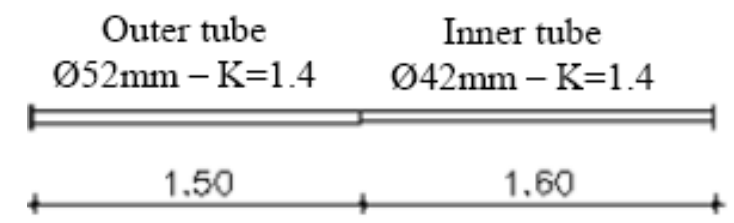

Fig. 15. Geometry of the 3rd Hypothesis using inner and outer tube.

After the application of the Equation 1 to 7 was obtained axial force resistance $\left(N_{c, R d}\right)$ equal to $1618.0 \mathrm{kgf}$ for inner tube and $3590.0 \mathrm{kgf}$ for outer tube. Thus, is possible to conclude that the prop collapse occur in the inner tube because of the less load capacity.

\section{COMPARISON OF RESUlTS}

In this chapter were compared the numerical and analytical results with the experimental one. The Fig. 16 resumes the comparison of the critical load between: Experimental; Computational (FLEP1 and FLEP2); and Analytical (NBR1, NBR2 and NBR3) results.

The $2^{\text {nd }}$ model of the computational study (FLEP2) was more approached of the experimental test than $1^{\text {st }}$ model (FLEP1). The critical load for FLEP2 was 4\% less than the experimental value. The analytical study with NBR1 (inner tube) and NBR2 (outer tube) were realized only to understand the element behavior and computational calibration. It is not apply in real case. The third hypothesis, NBR3, (used inner tube and outer tube with buckling coefficient $k$ equal to 1.4 ) showed result $2 \%$ less than the experimental test.

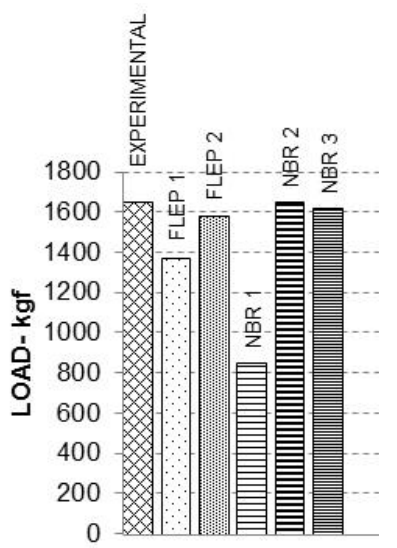

Fig. 16. Comparison of the critical load.

\section{CONCLUSION}

The FLEP program proved to be a reliable tool for computational analysis of steel prop. Justified by the fact that the result of his critical load was only $4 \%$ lower compared to the experimental trial. The experimental test is the best way to define the permissible load of the steel prop. After the experimental study was possible to calibrate the analytical study with NBR3, adopted buckling coefficient equal to 1.4. It is not exist in literature.

\section{REFERENCES}

[1] R. B. Rezende, "Uma visão sobre o uso de formas e escoramentos em cidades de grande, médio e pequeno porte do Brasil central e as novas diretrizes normativas," Dissertação de Mestrado em Engenharia Civil, Universidade Federal de Uberlândia, Uberlândia, 2010.

[2] S. Vaux, C. Wong, and G. Hancock, "Sway stability of steel scaffolding and formwork systems." in Proc. the International Conference on Advances in Steel Structures, vol. 1, pp. 311-319, 2002.

[3] J. J. Souza, "Proposta de requisitos de desempenho para execução de escoramento metálico em obras de construção civil," Dissertação de Mestrado em Engenharia Civil, Universidade de Pernambuco, Recife, 2011.

[4] B. Milojkovic, R. G. Beale, and M. H. R. Godley, "Determination of the factors of safety of standard scaffold structures," in Proc. The International Conference on Advances in Steel Structures, vol. 1, pp. 303-310, 2010.

[5] H. B. Liu, Q. H. Zhao, X. D. Wang, T. Zhou, D. Wang, J. Liu and Z. H. Chen. "Experimental and analytical studies on the stability of structural steel tube and coupler scaffolds without X-bracing," Engineering Structures, vol. 4, pp. 1003-1015, 2010.

[6] J. L. Peng, A. D. E. Pan, and W. F. Chen, "Approximate analysis method for modular tubular falsework," ASCE J. Struct. Eng., vol.127, pp. 256-263, 2001.

[7] S. Barakat, "Experimental compression tests on the stability of structural steel tabular props," Jordan Journal of Civil Engineering, vol. 5 , no. $1,2011$.

[8] R. C. Hibbeler, Resistência Dos Materiais, $5^{\text {a }}$ ed. São Paulo: Pearson Prentice Hall, 2004.

[9] Projeto De Estruturas De Aço E De Estruturas Mistas De Aço e Concreto De Edificios, ABNT Associação Brasileira de Normas Técnicas. NBR 8800. Rio de Janeiro, 2008.

[10] F. J. P. Almeida, "FLEP - Flambagem Linear Elástica de Pórticos Planos," Ferramenta Didática (Curso de Engenharia Civil) Universidade Federal do Ceará -Campus Cariri, Juazeiro do Norte 2010.

[11] Projeto, Dimensionamento e Procedimentos Executivo De Fôrmas e Escoramentos Para Estruturas De Concreto, ABNT Associação Brasileira de Normas Técnicas. NBR 15696. Rio de Janeiro, 2009.

[12] H. L. Soriano and S. S. Lima, nálise de Estruturas: Método Das Forças e Método Dos Deslocamentos, $2^{\mathrm{a}}$ Ed. Editora Ciência Moderna Ltda Rio de Janeiro, 2006. 


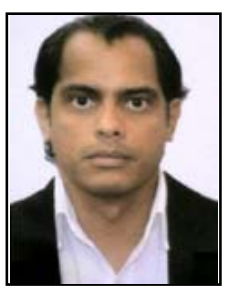

Cleirton André S. De Freitas was born in 1976 and he is from Fortaleza city in Brazil. He has been finished the course of technician in mechanics in 1996 at Federal Technical School of Ceará. He was graduated in civil engineering at the Federal University of Ceará in 2002. He received his masters in structures and construction from University of Brasilia in 2005 and He received his $\mathrm{PhD}$ in structural and civil engineering from University of Brasilia in 2008. He developed studies in three-dimensional modeling, finite element and experimental tests. Relevant experience in projects of concrete structures and steel into works of hydropower at ENGEVIX S/A. Currently he is a professor in effective civil engineering at the Federal University of Cariri.

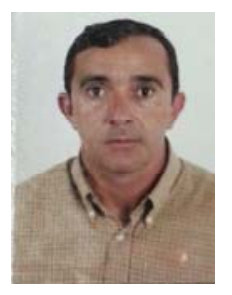

Francisco José P. De Almeida is from Fortaleza city, Brazil and he was born in 1960 . He has been graduated in civil engineering from the Federal University of Ceará (in 1983) and He received his masters in civil engineering from the Pontifical Catholic University of Rio de Janeiro in 1985. He is working on stress analysis on components of rockets at the Institute of Aeronautics and Space construction (ITA). He is currently an assistant professor at the Federal University of Cariri (UFCA) and Develops computational programs for analysis using finite elements. He is the author of FLEP. 